\title{
WAVERING OVER BORDERLINES: HISTORY AND FICTION IN WALTER SCOTT
}

\section{Sandra Guardini Teixeira Vasconcelos*}

Universidade de São Paulo

All historical novels, by definition, travel through time, into the past; some of them travel through space as well, foregrounding a journey which leads the main character to tread unknown territories, cross physical and/or cultural borders, fight wars, help expand national frontiers. Often, this movement in space also becomes movement in time, with physical mobility literally causing the protagonist to confront temporal displacement and cultural difference. Walter Scott's Waverley Novels are a case in point. Generally speaking, the quintessential Scott plot has been described as the story of an Englishman or a Lowland Scotsman who travels north to the Highlands, at a time when national feeling is running high, becomes entangled, partly by accident, partly by sympathy, in local disputes, finally returning home, somewhat changed by the experience (Daiches, "Scott's Achievement" 92-93). This could at some level be characterised as one more specimen of the Bildungsroman, however, it acquires further meanings as Scott plunges this individual into the current of the sociohistorical forces that were shaping modern Scotland, thus conflating the private and the public spheres and mingling fiction and History. Whereas the narrative takes

\begin{tabular}{|l|l|l|l|l|}
\hline Ilha do Desterro & Florianópolis & no 57 & p. 139-155 & jul./dez. 2009 \\
\hline
\end{tabular}


the hero into a journey of self-discovery, it also acquaints him with a broad sweep of territory -Scott refers to "all ranks of [his] countrymen" (Waverley353)-, granting him, and the reader, access to geographically and socially new areas. Therefore, one could argue, as has Franco Moretti, that this northbound journey is above all anthropological in nature, since crossing the Anglo-Scottish border drives the protagonist backwards through "various stages of social development" into clan life and an older, more heroic Scotland (37-38). The coexistence of different temporalities in the novel, with an interpenetration of the old and the new, reproduces the cultural discontinuities of a divided country between Jacobites and Hanoverians, between traditional, tribal, Gaelicised Scotland and the new, Anglicised, commercial post-Culloden society. Scott's "middle-of the-road" hero is caught at this crossroads and made to look both into the past and into the future, as his journey is a means to establish close contact between the two regions and ages.

Set during the Jacobite uprising of 1745-1746, Waverley (1814) narrates the adventures of Edward Waverley, a young English aristocrat who is posted to the Lowlands as an army officer and gets increasingly involved in civil war, through his acquaintance first with the Baron of Bradwardine and then with Fergus Mac-Ivor, the Highland chieftain of Glennaquoich, to finally join the rebellious troops of Prince Charles Edward Stuart (Bonnie Prince Charlie), the pretender to the British throne, against the house of Hanover. His first move into another age takes place at Tully-Veolan, in Perthshire, the estate which the Baron rules as a truly feudal lord. On arrival, Edward experiences his first encounter with a new and unfamiliar temporal dimension and social order. The legislation to put an end to feudal relationships and bondage between lords and tenants was only to be introduced in 1748, and vassalage and hereditary jurisdiction were still ongoing practices when Edward receives his first impressions of the "misery and dirt of the hamlet" which we soon suspect to be a direct consequence of the Baron's manorial rights over his property: 
The whole scene was depressing, for it argued, at the first glance, at least a stagnation of industry, and perhaps of intellect. [The villagers] stood and gazed at the handsome young officer and his attendant .... It seemed, upon the whole, as if poverty, and indolence, its too frequent companion, were combining to depress the natural genius and acquired information of a hardy, intelligent, and reflecting pesantry. (33)

Shabbiness, however, seems to be general, as the narrator suggests, referring to the mutual dependency that still prevailed between proprietor and tenants:

This dove-cote ... was no small resource to a Scottish laird of this period, whose scanty rents were eked out by the contributions levied upon the farms by these light foragers, and the conscriptions exacted from the latter for the benefit of the table. (35)

Despite Bradwardine's status, authority and social privilege, the dilapidated appearance of the house of Tully-Veolan stands as a decaying symbol of ancient feudal power, while revealing the effects of forty years of economic union with England. All of this and also the way of life of the Baron and his neighbours the outsider Edward has the opportunity to observe while a guest at the property. That, however, will prove to be only the first stage of his journey into an entirely new world, initially introduced to him through strange-sounding names, accounts of "deeds of violence" and "particulars concerning the manners, customs, and habits, of [a] patriarchal race" which Edward will soon be able to discover and see for himself (72-73).

His first vision of what lies beyond the "huge gigantic masses" in Perthshire, in striking contrast with the "more level country" where Cosmo Comyne Bradwardine of Bradwardine lives (32), comes in the form of a "mountaineer in his full national costume" (73). ${ }^{1}$ The man is 
Evan Dhu Maccombich and on his invitation Waverley will cross the Highland Line and witness the sharp change in topography, scenery and vegetation, but above all in way of life, on the other side of the ridge. Edward's spirit of adventure is roused first by his visit to the lair of Donald Bean Lean, a Highland freebooter, and then by the great hall at Glennaquoich, home to the young Highland chieftain and fiery Jacobite Fergus Mac-Ivor and headquarters of a patriarchal society where chieftain and followers feast together bound by ties of kinship.

Language, for they all speak Gaelic among themselves, is the least of the differences or difficulties Waverley will experience in this plunge into a world which will require decipherment and interpretation at every move. Edward's anthropological journey starts with Evan Dhu as guide and informer, "illustrating the existing state of the Highlands" (88), and what he will see and learn about is how clan life is organised round the figure of Fergus, whose command and patriarchal power over his vassals (a "feudal militia") are exercised for the sake of the Stuart cause. Fergus's "rude mansion" brings together the sons of Ivor, dependants and adherents, the clansmen soon to rise in their struggle for the restoration of the Young Pretender.

As Edward crosses the Scottish border, therefore, he penetrates a new temporal dimension, farther and farther removed from his own present, into different stages of civilisation and states of society. At Glennaquoich, it is an old, traditional system that still obtains, a pre1748 tribal organisation that preserves the ancient Highland unit of the clan and a communal culture, with the Highlanders as "the order of the primitive ... still structurally present within modernity" (Duncan xxiv). The novel displays a nonlinear conception of progress, and its historical layering binds together heterogenous times and spaces, including that of the narrator, who tells the story from a distance of sixty years, made explicit in the refrain that echoes throughout. ${ }^{2}$ Scotland is thus constructed not as a "nation" but rather as a divided territorial and cultural entity, and site of a dramatic clash between barbarism and civilisation, Highland and Lowland, old and new. 
By setting his action in the year 1745 , Scott chooses to address the internal divisions, mainly political, which were tearing Scotland apart. His historical consciousness was stressed by a critic like Georg Lukács, one of the first twentieth-century critics to reappraise the novelist's invention of a new novel form. ${ }^{3}$ As the Hungarian critic remarks, novels with historical themes had been written before, but they had limited themselves to a "purely external choice of theme and costume" (19). Scott's sense of historical necessity, on the contrary, enabled him to represent men and events historically and to show "how this necessity $\mathrm{ha}[\mathrm{d}]$ its roots in the real social and economic basis of popular life" (59). Rather than privileging the great historical personages, the Scottish novelist chooses the mediocre, prosaic hero as his central figure and makes him representative, while he transforms his plots into a condensation of dramatic facts which embody a national crisis. In this move, Lukács saw the "great objectivity of the great epic writer" who portrays "the struggles and antagonisms of history by means of characters who, in their psychology and destiny, always represent social trends and historical forces (34).

Scott depicts critical moments in the history of Scotland, those in which he captures a new social order being built on the wrecks of the old one, and creates a new form to meet the challenge of giving literary shape to a new way of understanding history, of apprehending the relation between past and present and of exposing the sociohistorical forces that shape men's daily life. In an essay of 1818, Lord Macaulay praised in Scott's work this exploration of areas in the past which had been so far neglected by historians:

Sir Walter Scott, in the same manner, has used those fragments of truth which historians have scornfully thrown behind them in a manner which may well excite their envy. He has constructed out of their gleanings works which, even considered as histories, are scarcely less valuable than theirs. But a truly great historian would reclaim those materials 
which the novelist has appropriated. The history of the government, and the history of the people, would be exhibited in that mode in which alone they can be exhibited justly, in inseparable conjunction and intermixture. We should not then have to look for the wars and votes of the Puritans in Clarendon, and for their phraseology in Old Mortality; for one half of King James in Hume, and for the other half in the Fortunes of Nigel. ${ }^{4}$

Scott had experienced from very close the intellectual atmosphere of late eighteenth-century Scotland, where the thought of philosophers of history such as David Hume, Adam Ferguson and William Robertston was in force, ${ }^{5}$ with which the novelist had direct or indirect contact. The country's "formal loss of national identity" had stimulated interest in the nature of the historical process and transformed the relation between tradition and change into the raw material of Scottish culture in the 18th century (Daiches, "Sir Walter Scott" 461-62). As a Law student and member of the Speculative Society, Scott had the opportunity to take part in the contemporary debate, and access to a perspective which translated into a "deep sense of the essentially social nature of history, ... sophisticated determinism, ... sharp awareness of the effects of historical environment on behaviour" (Garside 497). Integral to the discussion of these thinkers, the theoretical investigation about the historical process was especially important in shaping Scott's stance, since it drew attention to historical change, to crises and the ways by which the past flows into the present. Tradition, legend and folklore, so fundamental in his novels, become crucial elements for the understanding of the different life forms on both sides of the border, of the divisions between English and Scottish, and between the Highlands and the Lowlands. Scott's historical imagination, at work mainly in his novels of the Scottish cycle, enabled him to recreate and enact the customs and everyday life of men of other times, connecting the feelings and practices of his characters with the milieu in which they lived. 
As interrogations about the meaning of the past and the ways we can come to know it, the Waverley Novels reveal a historical vision which arises from their sense of place, geography and social environment. History, then, mattered to Scott as a process, with its gains and losses, even if the past, seen as the pre-history of the present, could no longer be retrieved but only glimpsed in its tensions and discontinuities. Lessening the centrality of the great historical events, the novelist preferred to dwell on what Francis Jeffrey, the editor of the Edinburgh Review, once described as "the silent undercurrent of life" (216-17). Im sum, the Waverley Novels map out the human costs of the changes operating throughout the turbulent history of Scotland, with the "middling" hero at the centre of the action, a common man who, moving between two distinct ages, two different cultures, two opposite social forces, mediates the conflicts and embodies their impasses.

The discord between Jacobites and Hanoverians, which eventually led to the 1745 uprise, is brought to the fore and incorporated into the plot with this wavering ${ }^{6}$ hero literally shifting between the two warring parties. As Edward Waverley witnesses the military preparations for war, his closeness to the Mac-Ivors due to his admiration for, and friendship with Fergus, and his love for Flora increasingly draw him to the antagonistic camp, at this time of disorder and unrest, political strife and change, not without some distress for his awareness that he is rising "against an established government" (132). The former "officer in the service of the Elector of Hanover" becomes thus directly entangled in the internal complications of Scottish national politics (131).

Scotland's "traumatic experience of the formal loss of national identity" resulting from its Union with England in 1707 is the shadow that hangs over the contemporary events Waverley foregrounds. Internal colonialism, or the process of the country's political and cultural assimilation to England, pervades the novel as a whole, with the 1745 Rebellion as the last attempt to restore the Stuarts to the throne (Daiches, "Sir Walter Scott" 461). The defeat of the Jacobite rebels at the Battle of 
Culloden in 1746 comes then as the final blow and paves the way for the forging of a new nation-state, with the break-up of the clan system, "the assimilation of the Scottish Gaelic populations to the modern state" and "the achievement of national unity upon the suppression of a traditional native culture" (Duncan viii).

The journey thus becomes a central narrative device to enable this mobility across social, political and cultural divides. Rather than being an opportunity for observation or description of the natural scenery, it is the human landscape that matters to the outsider who is forced to exercise his gaze in his reading of a new reality. Scotland presents itself to the protagonist as a maze of "blind road[s]" which are trodden unknowingly but demand analysis and evaluation all the same. From the accusation of high treason, imprisonment, his rescue by the Highlanders and his joining the rebels, Waverley covers a lot of physical, emotional and cultural ground. Because he has chosen to take a "journey through the country at this unfortunate and distracted time" (155), he has to make his way through "the rude eye of rebellion" $(166)^{7}$ but in consequence is able to chart and directly participate in the course of history. The sequence of battle scenes can be definitely considered as the climax of the novel for bringing together the opposite political forces in action, dramatising the "ill-fated and desperate undertaking of $1745^{\prime \prime}$ (206) and setting in motion the resolution of Waverley's and Fergus's personal fates. Their epic character, pointed out by Lukács, derives from "the interaction between 'above' and 'low', the sum total of which constitutes the totality of popular life" (Lukács 49). Indeed, from a craggy eminence, the protagonist, and the reader contemplate the rebellious forces and the impressive, "remarkable spectacle" of the Highlanders' march. What comes within view, apart from the chiefs and leading men of each clan, all gentlemen well armed with broadswords, fusees and pistols, is the peasantry of the country, bearing "the livery of extreme penury, being indifferently accoutred, and worse armed, half naked, stinted in growth, and miserable in aspect" (214). The narrator calls them Helots, referring to the unfree population group inhabiting areas of Sparta whose status was little more than that of 
slaves, since, like them, these "hereditary servants" had been "forced into the field by the arbitrary authority of the chieftains" (221). Differences of class, as Waverley observes them, are only part of his awareness of other distinctions, which become visible when he finds himself marching with the Jacobite army out of Edinburgh. There and then, he confronts a climactic moment of realisation of otherness but also of self-estrangement:

It was at that instant, that looking around him, he saw the wild dress and appearance of his Highland associates, heard their whispers in an uncouth and unknown language, looked upon his own dress, so unlike that which he had worn from his infancy, and wished to awake from what seemed at the moment a dream, strange, horrible and unnatural. (221)

Moreover, for the first time he strips these men of the romantic aura which he had covered them with and sees them in all their strangeness:

the character and appearance of their [Highlands] population, while thus sallying forth as military adventurers, conveyed to the south country Lowlanders as much surprise as if an invasion of African negroes, or Esquimaux Indians, had issued forth from the northern mountains of their own native country. (214)

The comparison is telling. Something utterly unfamiliar seems to lie in the heart of Scotland, bringing to light its internal divisions and giving them full body and shape. The insurrection is, therefore, a settling of accounts with both the Scottish past and present, becoming the visible face of an ancient distrust and of differences which, to the Scotsmen themselves, even if they had never been completely overlooked, all of a sudden surfaced as open and avowed conflict. Looking more like a nightmare than an adventurous journey into a 
foreign land, Waverley's experience of civil war obliges him to forsake "the colouring of a warm and vivid imagination" to face "the cold, dry, hard outlines which history delineates" (57). His act of heroism and the Jacobite victory at Prestonpans do not obliterate the "scene of smoke and slaughter" (226) he observes from his post, and will soon evolve into "the calamitous termination of their rash undertaking" (264) to take place at the Battle of Culloden in 1746, with the final defeat of the insurgents by the Duke of Cumberland. Climactic from a political and historical perspective, these events also represent a turning point in Waverley's life and the culmination of his process of apprenticeship. Among the "wrecks" and the "marks of ravage," he comes out of his long journey "a sadder and a wiser man." At last, once he has been able to extricate himself from the accusation of high treason, he is now ready to come back to England and Waverley-Honour and settle down into domestic life.

From a vantage point firmly rooted in the present, the distanced and often ironical narrator looks into the recent past of Scotland to interpret it and probe the origins of his own time. This distance is marked by the refrain - "sixty years since," which pervades the whole narrative and helps create an intricate temporal structure that comprehends both the events of the protagonist's present, interspersed with even more ancient references (like those to the 1715 campaign), and the narrator's own age, which has already absorbed the changes Waverley witnessed and has come to constitute a new social order. The passage from one time to the other, from one order to the other, probably finds its best translation at the end of the narrative in the painting which portrays Fergus Mac-Ivor and Edward Waverley in their Highland dress against a "wild, rocky and mountainous" background. While the picture contrasts "the ardent, fiery, and impetuous character of the unfortunate Chief of Glennaquoich" and "the contemplative, fanciful, and enthusiastic expression of his happier friend" (338), it also figures the death of the heroic world, feudal power and patriarchal authority embodied by the son of the tribe of Ivor, and the rise of a new modern civilisation, personified by Edward. History has destroyed Fergus, but it has also awakened Waverley from his romantic dreams, disciplined 
his expectations and accommodated him to a bourgeois and domestic life, represented by his marriage to Rose Bradwardine and settlement as the lawful heir to Waverley-Honour (Levine 104).

Critics have frequently read this denouement as Sir Walter Scott's symbolic reconciliation of political conflict and acquiescence to Scotland's submission to England, with the consequent disappearance and displacement of a Scots identity into a British one. However, 1746 entailed more than just Scotland's loss of independence; it also meant the last failed attempt to restore absolute monarchy, which the revolutionary era between 1640 and 1688 had put an end to in the British Isles, the vanishing of the feudal state and the open road to the development of a bourgeois society (Nairn 15-16). In fact, Scott's postscript to the novel (339) ${ }^{8}$ shows us a writer particularly conscious of the historical implications of the changes he has just about tried to give voice to:

There is no European nation which, within the course of half a century, or little more, has undergone so complete a change as this kingdom of Scotland. The effects of the insurrection of 1745 , - the destruction of the patriarchal power of the Highland chiefs, - the abolition of the heritable jurisdictions of the Lowland nobility and barons, - the total eradication of the Jacobite party, which, averse to intermingle with the English, or adopt their customs, long continued to pride themselves upon maintaining ancient Scottish manners and customs, commenced this innovation. The gradual influx of wealth, and extension of commerce, have since united to render the present people of Scotland a class of beings as different from their grandfathers, as the existing English are from those of Queen Elizabeth's time. (340)

It is virtually impossible not to hear in these words Scott's hail to modernity. This is the social historian speaking, with his sense of the real processes going on in Scotland, "the man who knows that history cannot stand still, that there can be no change, even for the better, without 
loss, suffering, and waste," Scott has been accused of writing costume drama and immortalising the tartan, clans and bagpipes, and the picturesque, as tokens of national identity (Mayhead 43). Rather, each one of his Waverley Novels is an investigation and exploration of key events in Scottish history. As Gary Kelly pointedly summarises,

Scott's principal subject in his first eight novels is the 'modernization' of Scottish society, that is, its transformation, through a series of historical crises, from a society that was agrarian, aristocratic, court-dominated, feudal, often fanatically religious, mainly oral, lacking in effective public institutions, and based on personal loyalties, to a society that is open, urban as well as rural, gentry-dominated, capitalist, professionalized, rational, literate, with more effective public institutions (especially the law), and with a strong sense of 'national' identity and interest transcending class differences. (141)

With this move, Scott also gave the novel a much more dignified status than it had ever enjoyed. In his hands, the genre became a crucial instrument in the definition of the nation as an "imagined community" - what has been described as his eye for Scottish character and ear for Scots dialogue made an enormous contribution to shaping a narrative of identity and forming a national imaginary. In his many journeys into the past, he mapped out how "the internal periphery" came to be incorporated "into the larger unit of the state" of Great Britain (Moretti 40). The romantic Sir Walter Scott never erased the ambiguities and tensions involved in the process and, rather than constructing Scotland as a homogenous, unified and continuous entity, he realistically enacted the dynamic movement of history by foregrounding the nation's disruptions and discontinuities (McCracken-Flesher).

Scott has been described as "the architect of cultural Scottishness" (McCracken-Flesher 3), the first of a lineage of writers to take upon themselves the task of representing the nation after the loss of the sheer 
possibility of independent statehood at Culloden in 1746, and the reconfirmation of Scotland's union with England. ${ }^{9}$ In the wake of the paradigmatic example of Cervantes and Fielding, two of his admittedly favourite authors, Scott launched his heroes and heroines, like "the heroic travellers in the Odyssey" (Waverley 95), into expeditions of discovery, thus helping his countrymen articulate a national consciousness, with the narrator functioning as a kind of translator between England and a Gaelicised Scotland. His mediating role, however, has not always been worthy of praise. Some, like Murray Pittock, blame him for "the depoliticisation of the Jacobite sensibility," while suggesting that "Scott's romantic engagement with the past ultimately resulted in the imaginative impossibility of a Scottish national-historical continuity independent of England" (Pittock qtd in Boccardi 97).

Discussions of nationalism, nationhood and national identity are always problematic and potentially dangerous. Whatever may have been Scott's political convictions and literary project, if he had one, his Scottish novels realistically depict a period of historical convulsion with a sense of honesty and real concern about the destiny of his homeland, as he makes explicit from the very start:

By such efforts, feeble as they are, I may contribute somewhat to the history of my native country; the peculiar features of whose manners and character are daily melting and dissolving into those of her sister and ally. And, trivial as may appear such an offering, to the manes of a kingdom, once proud and independent, I hang it upon her altar with a mixture of feelings, which I shall not attempt to describe. (Scott, Minstrels)

His keen interest in all things historical may have also given him a sharp understanding of what was at stake at the moment he decides to move from poetry to the novel. As Harry Shaw has pointed out, 
Faced with what he perceived as Napoleon's attempt to homogenize all of European culture, Scott felt compelled to sacrifice Scottish independence in the name of preserving the possibility of saving any cultural particularity at all, and not just in Scotland. A Great Britain large and strong enough to frustrate Napoleon's ambitions was required. Scott the Scottish patriot thus found himself in league with the English colonizer, as an apologist for the Union between England and Scotland that had occurred a century before. (182)

Wavering over different types of (un)certain borderlines - between Scotland and England, the Highlands and the Lowlands, History and fiction -, Scott's novels also crossed other frontiers, taking other readers on their journey. Travelling from Europe to distant countries, they crossed the Atlantic and made their way into the port of Rio de Janeiro and across the hills of Minas Gerais. The English traveller George Gardner recalls a journey to Diamantina: "Em uma das casas que ocasionalmente visitei encontrei traduções portuguesas de Ivanhoe e Guy Mannering, de Sir Walter Scott. Haviam sido enviadas do Rio de Janeiro a uma das filhas da família, que as lera com a maior admiração" (211). ${ }^{10}$

To this anonymous admiring reader we could still add the Visconde de Taunay, who recorded the "verdadeiro deslumbramento" (true fascination) which Ivanhoe had provoked when he read it around 1852 (58), or José de Alencar, in his public acknowledgement of his literary debts: “Devorei os romances marítimos de Walter Scott e Cooper, um após outro; ... Li nesse decurso muita coisa mais: .... Mas nada valia para mim as grandiosas marinhas de Scott e Cooper e os combates heróicos de Marryat (144). ${ }^{11}$

Like Waverley, Scott has also journeyed through unfamiliar territories, exploring the potentialities of the history of his native country, investigating the past, trying to understand the present; similarly, his novels sailed to distant lands, and inspired novelists who, as he had done, were soon to embark on their own literary projects, many involving, like Scott's, considerations of national or cultural identity. 
When Alencar confesses his interest in Scott's work, he entices us to also embark on a critical adventure and a new journey of discovery. ${ }^{12}$

\section{Notes}

* This article presents some preliminary results of the research project being carried out thanks to a Bolsa de Produtividade em Pesquisa granted by CNPq. A CAPES post-doctoral Grant in 2008 gave me access to the critical bibliography on Sir Walter Scott.

1. The narrator mentions "the short kilt, or petticoat," the "goat-skin purse," his pistol, his feathered bonnet and his sword (73).

2. "Tis Sixty Years Since" is not only the subtitle of the novel but a kind of refrain, frequently used by the narrator.

3. Seehis The Historical Novel. Lukács was responsible for Scott's critical rehabilitation in the $20^{\text {th }}$ century.

4. Thomas Macaulay. "History." http://www.gutenberg.org/etext/2168.

5. "This is the historical age and we are the historical people," used to say David Hume, nephew of the philosopher and professor of Scottish Law at the University of Edimburgh (Daiches, "Sir Walter Scott" 458).

6. The choice of the main character's surname cannot go unnoticed: "waver" means to move unsteadily back and forth, but also to exhibit irresolution or indecision, to vacillate. As Fergus says of him, "you are blown about with every wind of doctrine" (Waverley 237).

7. The quotation is from Shakespeare's King John.

8. Cf. "A Postscript, which should have been a Preface", Chapter LXXI (or Volume III, Chapter XXV).

9. The opening of the Scottish Parliament on 1 July 1999 was the first since 1707.

10. At one of the houses that I sometives visited, I found Portuguese translations of Ivanhoe and Guy Mannering, by Sir Walte Scott. They had been sent from Rio de Janeiro to tone of the daughters, who had read them with the greatest admiration. 


\section{Sandra Guardini Teixeira Vasconcelos}

11. I devoured the sea novels by Walter Scott and Cooper, one after the other... In that period I read much else... But nothing for me was as valuable as the grandiose seas adventures of Scott and Cooper and the heroic combats of Marryat.

12. This is the project I am carrying out at the moment, with still very preliminary and not yet published results.

\section{References}

Alencar, José de Alencar. Obra Completa. Vol. 1. Rio de Janeiro: Ed. José Aguilar, 1959.

Boccardi, Mariadele. "Pedlars of their Nation's Past: Douglas Galbraith, James Robertson and the New Historical Novel." The Edinburgh Companion to Contemporary Scottish Literature. Ed. Berthold Schoene. Edinburgh: Edinburgh UP, 2007. 97-105.

Daiches, David. "Scott's Achievement as a Novelist." Literary Essays. Chicago: The University of Chicago Press, 1967. 88-121

. "Sir Walter Scott and History." Études Anglaises 24.4 (1971): 458-77.

Duncan, Ian. Introduction to Rob Roy. Rob Roy. By Sir Walter Scott. Oxford: Oxford UP, 1998. i-xxv.

Gardner, George. Viagem ao Interior do Brasil, principalmente nas províncias do Norte enos distritos do ouro e do diamante durante os anos de 1836-1841. Belo Horizonte: Ed. Itatiaia; São Paulo: Ed. da Universidade de São Paulo, 1975.

Garside, Peter D. "Scott and the 'Philosophical' Historians." Journal of the History of Ideas 36 (July-Spetember 1975): 497-512.

Jeffrey, Francis. Edinburgh Review 28 (March-August 1817): 216-17.

Kelly, Gary. English Fiction of the Romantic Period, 1789-1830. Essex: Longman, 1989.

Levine, George. The Realistic Imagination. English Fiction from Frankenstein to Lady Chatterley. Chicago: The U of Chicago P, 1981.

Lukács, George. The Historical Novel. Trad. Hannah and Stanley Mitchell. Lincoln: U of Nebraska P, 1983. 
Macaulay, Thomas Babington. "History." The Miscellaneous Writings and Speeches of Lord Macaulay. 30 April 2007. < http://www.gutenberg.org/etext/2168,>.

Mayhead, Robin. Walter Scott. Cambridge: Cambridge UP, 1973.

McCracken-Flesher, Caroline. Possible Scotlands. Walter Scott and the Story of Tomorrow. Oxford: Oxford UP, 2005.

Moretti, Franco. Atlas of the European Novel. London: Verso, 1998.

Nairn, Tom. The Break-up of Britain. London: New Left Books, 1981.

Scott, Walter. General Preface (1829). Waverley; or, 'Tis Sixty Years Since. Oxford: Oxford UP, 1998.

. Minstrelsy of the Scottish Border. Vol. I. Appendix 1, 1806. 30 April 2007. <http://www.gutenberg.org.>. . Waverley; or, 'Tis Sixty Years Since. Oxford: Oxford UP, 1998.

Shaw, Harry E. Narrating Reality: Austen, Scott, Elliot. Ithaca and London: Cornell UP, 2004.

Taunay, Visconde de. Memórias. São Paulo: Iluminuras, 2005. 
